\title{
Influence of Sowing Times, Densities, and Soils to Biomass and Ethanol Yield of Sweet Sorghum
}

\author{
Tran Dang Xuan ${ }^{1, *}$, Nguyen Thi Phuong ${ }^{2}$, Do Tan Khang ${ }^{1}$ and Tran Dang Khanh ${ }^{3}$ \\ 1 Graduate School for International Development and Cooperation, Hiroshima University, \\ Hiroshima 739-8529, Japan; E-Mail: dtkhang@ctu.edu.vn \\ 2 Vietnam Academy of Agricultural Science (VAAS), Ha Noi, Vietnam; E-Mail: ginemu@gmail.com \\ 3 Agricultural Genetics Institute (AGI), Hanoi, Vietnam; E-Mail: khanhkonkuk@gmail.com \\ * Author to whom correspondence should be addressed; E-Mail: tdxuan@hiroshima-u.ac.jp; \\ Tel./Fax.: +81-82-424-6927.
}

Academic Editor: Susan Krumdieck

Received: 2 May 2015 / Accepted: 27 July 2015 / Published: 25 August 2015

\begin{abstract}
The use of biofuels helps to reduce the dependency on fossil fuels and therefore decreases $\mathrm{CO}_{2}$ emission. Ethanol mixed with gasoline in mandatory percentages has been used in many countries. However, production of ethanol mainly depends on food crops, commonly associated with problems such as governmental policies and social controversies. Sweet sorghum (Sorghum bicolor (L.) Moench) is one of the most potential and appropriate alternative crops for biofuel production because of its high biomass and sugar content, strong tolerance to environmental stress conditions and diseases, and wide adaptability to various soils and climates. The aim of this study was to select prospective varieties of sweet sorghum, optimum sowing times and densities to achieve high yields of ethanol production and to establish stable operational conditions in cultivating this crop. The summer-autumn cropping

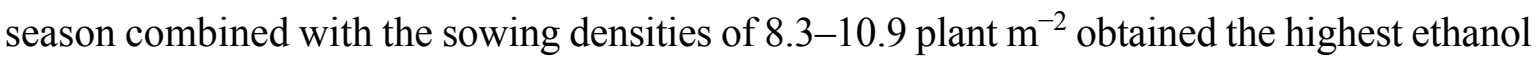
yield. Among cultivated locations, the soil with $\mathrm{pH}$ of 5.5 and contents of $\mathrm{Al}$ and $\mathrm{Zn}$ of 39.4 and $0.6 \mathrm{~g} \mathrm{~kg}^{-1}$, respectively, was the best condition to have an ethanol yield $>5000 \mathrm{~L} \mathrm{ha}^{-1}$. The $\mathrm{pH} \geq 6.0$ may be responsible for the significant reduction of zinc content in soils, which decreases both biomass of sweet sorghum and ethanol yield, while contents of N, P, K, organic carbon (OC) and cation exchange capacity (CEC), and Fe likely play no role. The cultivar $4 \mathrm{~A}$ was the preferred candidate for ethanol production and resistant to pests and diseases, especially cut worm (Agrotis spp.).
\end{abstract}


Keywords: ethanol; sweet sorghum; ethanol yield; biomass; sowing time; pests and diseases

\section{Introduction}

Air pollution can be reduced by oxygenating fuel for vehicles. Fischer et al. [1] indicate that MTBE (methyl tert-butyl ether) is a member of a group of chemicals commonly acknowledged as fuel oxygenates, commonly used as and is a fuel additive used to raise the octane number in vehicle fuel. However MTBE is very soluble in water and is reported as a possible human carcinogen [2]. Thereby, it should be better replaced by other oxygenated compounds to enhance the octane number of the fuels. Presently, ethanol as an oxygenous biomass fuel is the preferred alternative to MTBE for its biodegradable, low toxicity, persistence, and regenerative characteristics [3]. Ethanol has been produced from various crops such as sweet sorghum (S. bicolor), corn (Zea mays), wheat (Triticum aestivum), barley (Hordeum vulgare), sugar cane (Saccharum officinarum), sugar beet (Beta vulgaris), cassava (Manihot esculenta), and sweet potato (Imopoea batatas) [4]. Like most biofuel crops, sweet sorghum has the potential to reduce carbon emissions. In addition, this crop shows stronger tolerance than other crops under hot and dry climatic conditions. Its bagasse can be exploited as a byproduct including burning material for electronic generation, paper or fiber board manufacturing, silage for animal feed or fiber for ethanol production [5].

The ethanol production from biomass resources has been expanding rapidly, from 17.3 billion $\mathrm{L}$ in 2000 to 46.0 billion L in 2007 [6]. With all new government programs in America, Asia, and Europe, total global fuel ethanol demand can grow to exceed 125 billion L by 2020. In 2007, ethanol production represented about $4 \%$ of the 1300 billion L of gasoline consumed globally [6]. Ethanol has a higher octane number, broader flammability limits, and higher flame speeds and vaporization. The fuels with higher octane numbers are preferred in spark-ignition internal combustion engines [7]. Consequently, the use of ethanol as a gasoline substitute is a potential solution in mitigating the effects of greenhouse gas emissions and lowering the dependence on fossil fuels, which are currently becoming depleted and rising in price. Food crops like corn, grains, and cassava, destined for ethanol production face problems such as government policy and social controversy due to worldwide price increases of food crops and food shortage. Therefore, the development of alternative sources other than cereals for ethanol production is required.

Sweet sorghum (Sorghum bicolor (L.) Moench) is one among the leading potential crops for biofuel production [8]. As a $\mathrm{C}_{4}$ plant, it shows an impressive absorption of $\mathrm{CO}_{2}$ during its fast growth in 4-5 months [9-11]. The US, Brazil, Germany, India, and China have already produced ethanol from sweet sorghum, although the production is limited as compared to cassava, maize, and sugarcane [12,13]. It is well adapted to various types of soils and provides high production biomass production [14]. The stalks of sweet sorghum may obtain $8 \%-23 \%$ sugar content, depending on varieties and cropping seasons, and yield $>100$ tons $\mathrm{ha}^{-1}$ with high lignocellulose $[15,16]$. The use of cassava and maize for ethanol production has increased the world's staple prices and is a matter of social controversy, as many developing countries are facing a food shortage problem. Sweet sorghum as an alternative crop for 
ethanol production and therefore helps to increase farmers' income in developing countries. Thus, this crop also provides a great biomass for manure and cattle fed and can be grown even in infertile soil [17].

In Vietnam, cassava production ranges only after that of rice with an estimate of 8.5 million tons in 2010, and is the fourth greatest production in the world [18]. Most of cassava of the country is used to produce tapioca, and in a limited quantities of slices, cassava is used for the production of animal feeds or ethanol. However, it is uneconomical to produce ethanol from sliced cassava due to its low yields, unstable provision and significantly fluctuating price, and waste treatment is costly. In addition, these problems also attributed to the surging import from Thailand, Vietnam, and Indonesia to China for ethanol production, up from 257,000 tons in 2000 to more than 3.3 million tons in 2005 [19]. By 2012, about 780 million L of ethanol was produced from cassava also in China, requiring close to 6 million tons of dried cassava, much of which much was imported from Southeast Asia [20,21].

Since 2008, there have been four large scale ethanol producing plants using cassava with daily capacity of $100,000 \mathrm{~L}$ built in Vietnam, with the average capital investment \$80-100 million each. However, with the difficulties from the failure of wastewater treatment and unstable provision of cassava, many among them had to stop their ethanol production for several months. A tapioca factory with a capacity of 200 tons of cassava tubers per day may discharge approximately 100 tons of cassava waste. However, this waste is often dried in the sun before being used as raw material for produce animal feeds, resulting in the tendency of fungal and bacterial contaminations, posing the threat of aflatoxin production and environmental pollution to the air and water. Therefore, cassava waste has not been used in ethanol production in Vietnam [18]. Despite rice straw is a potential source for ethanol production, the lack of required technologies to produce high quanties of ethanol and difficulties in collecting rice straw in rural areas of Vietnam causes high prices [14]. In addition, production of ethanol from seaweed is also under research, due to Vietnam having an extensive freshwater network and a coastline of $3200 \mathrm{~km}$ and 639 seaweed species: of these belong 269 to Rhodophyta, 143 to Phaeophyta, 151 to Chlorophyta, and 76 to Cyanophyta [22].

The Vietnamese government has promoted ethanol development since 2007 [23]; with ethanol being primarily made from cassava and sugarcane molasses to produce the E5 (gasoline mixed with 5\% ethanol) that is sold at filling stations across the country [24]. However, to overcome the shortage provision and unstable prices of materials for ethanol factories, it is necessary to search for alternative crops to stabilize and extend ethanol production in Vietnam. Sweet sorghum (S. bicolor) is the most promising crop for biofuel production. As a $\mathrm{C}_{4}$ plant, it shows an impressive absorption of $\mathrm{CO}_{2}$ during a fast growth in 4-5 months. The US, Brazil, Germany, India, and China have already produced ethanol from sweet sorghum [5], and this plant is one of the three largest crops in US [25,26]. Its cultivation requires only $1 / 2$ and $1 / 3$ the water demand of maize and sugarcane, respectively, and lesser fertilizers. It has a wide adaption to many soils and provides high production of biomass. Depending on varieties and cropping seasons, the stalks of sweet sorghum may provide $8 \%-23 \%$ sugar contents and yields $>100$ tons $\mathrm{ha}^{-1}$ with high lignocellulose [27]. The yields of stems range from 40 to 50 tons ha $^{-1}$ while the grain yield is about 2 tons $\mathrm{ha}^{-1}[28]$.

Soil factors influence the growth and sugar production of sweet sorghum. They commonly include nutrients such as $\mathrm{N}, \mathrm{P}$, and $\mathrm{K}$ and minerals such as $\mathrm{Zn}$, Fe, and Al. Organic carbon (OC) and cation exchange capacity (CEC) are also important to determine soil health and associate with crop growth and productivity. Duncan [29] reported that the yield of sorghum grain was reduced by $19 \%$ as $\mathrm{pH}$ dropped 
from 6.6 to 5.0 and continuously decreased by $67 \%$ by $\mathrm{pH}$ of 4.4 . It was also noted that soil aluminum caused significant stress for sorghum. The amounts of $\mathrm{N}, \mathrm{P}$, and $\mathrm{K}$ in soils are critical to determine fertilizer doses incorporated to soils to increase the yields of sorghum as well as other crops [30,31]. Small amount of nutrients, particularly $\mathrm{Zn}, \mathrm{Fe}$, and $\mathrm{Mn}$ applied by foliar spraying significantly promote the yield of crops [32]. The content of $\mathrm{Al}$ in soil may cause $\mathrm{Al}^{3+}$ toxicity which is the primary factor limiting crop growth [33].

In Vietnam, the National Gene Bank has conserved hundreds of native sweet sorghum but they have not been much studied. In a preliminary experiment, our group has collected many inbred and hybrid sweet sorghum cultivars, including both inbred and hybrid, in Vietnam and different countries in Asia. This research was therefore conducted to (i) select the most potential cultivars of sweet sorghum with high sugar contents, providing great biomass and having strong tolerance to drought, pests and diseases; and (ii) to examine the effects of sowing times and densities, and soil factors on productivity including stem yield and sugar content, and ethanol yield of sweet sorghum.

\section{Experimental Section}

\subsection{Plant Materials}

A total of 66 sweet sorghum cultivars, with 54 Vietnamese native from Vietnam Gene Bank and the other 12 were from ICRRISAT (International Crops Research Institute for the Semi-Arid Tropics) were used in this research. Regarding their origin, 2 were from Laos, 14 from India, and 52 from Vietnam (Table 1).

\subsection{Field Preparation}

The sowing of the 66 varieties was designed in a completely randomized block, each of $3 \mathrm{~m}^{2}$ with three replicates. The experiment site was affiliated with Vietnam Agricultural Environmental Institute, Hanoi. The fields received conventional herbicides 2-4 weeks prior to ploughing. The seeds were sown on the beds at $6 \mathrm{~kg} \mathrm{ha}^{-1}$, at depth of $2-5 \mathrm{~cm}$. The seedlings of sorghum were then thinned at seven plants per $\mathrm{m}^{-2}$. The soil was fertilized at $\left(90 \mathrm{~N}+60 \mathrm{P}_{2} \mathrm{O}_{5}+60 \mathrm{~K}_{2} \mathrm{O}\right) \mathrm{ha}^{-1}$. All of the $\mathrm{P}_{2} \mathrm{O}_{5}$ was provided to soil before sowing. However, the nitrogen and kali were halved and applied at each 3-4 and 7-8 leave periods. The weeding at 3-4 weeks after sowing was done by hand, however from 7-8 leave period, the weeds were removed by hoes. Tap water was provided daily to keep the soil moisture at about $80 \%$. 
Table 1. Sweet sorghum cultivars.

\begin{tabular}{|c|c|c|c|c|c|c|c|c|c|}
\hline No & $\begin{array}{l}\text { Variety } \\
\text { name }\end{array}$ & Local name & $\begin{array}{l}\text { Registered } \\
\text { number+ }\end{array}$ & Origin & No & $\begin{array}{l}\text { Variety } \\
\text { name }\end{array}$ & Local name & $\begin{array}{l}\text { Registered } \\
\text { number }+\end{array}$ & Origin \\
\hline 1 & $1 \mathrm{~V}$ & Cao luong & 8967 & Vietnam & 21 & $21 \mathrm{~V}$ & Cao luong & 8989 & Vietnam \\
\hline 2 & $2 \mathrm{~V}$ & Cao luong Yen Chau & 8968 & Vietnam & 22 & $22 \mathrm{~V}$ & Cao luong nep hat & 8990 & Vietnam \\
\hline 3 & $3 \mathrm{~V}$ & Cao luong & 8969 & Vietnam & 23 & $23 \mathrm{~V}$ & Goi suai & 9840 & Vietnam \\
\hline 4 & $4 \mathrm{~V}$ & Cao luong & 8970 & Vietnam & 24 & $24 \mathrm{~V}$ & Quan dua lia & 9841 & Vietnam \\
\hline 5 & $5 \mathrm{~V}$ & Cao luong & 8971 & Vietnam & 25 & $25 \mathrm{~V}$ & Duoi huong & 9842 & Vietnam \\
\hline 6 & $6 \mathrm{~V}$ & Duoi nguoi & 8972 & Vietnam & 26 & $26 \mathrm{~V}$ & Oi nong nang & 9843 & Vietnam \\
\hline 7 & $7 \mathrm{~V}$ & Duoi nguoi bong ngan & 8973 & Vietnam & 27 & $27 \mathrm{~V}$ & Oi liem & 9844 & Vietnam \\
\hline 8 & $8 \mathrm{~V}$ & Duoi nguoi bong dai & 8974 & Vietnam & 28 & $28 \mathrm{~V}$ & Mac oi liem & 9845 & Vietnam \\
\hline 9 & $9 \mathrm{~V}$ & Bo bo & 8975 & Vietnam & 29 & $29 \mathrm{~V}$ & Coi chu rai dim & 9846 & Vietnam \\
\hline 10 & $10 \mathrm{~V}$ & Cao luong & 8976 & Vietnam & 30 & $30 \mathrm{~V}$ & Cao luong do & 12271 & Vietnam \\
\hline 11 & $11 \mathrm{~V}$ & Cao luong & 8977 & Vietnam & 31 & $31 \mathrm{~V}$ & Khau te & 12272 & Vietnam \\
\hline 12 & $1 \mathrm{~L}$ & Cao luong & 8978 & Laos & 32 & $32 \mathrm{~V}$ & Oi nong nang & 12273 & Vietnam \\
\hline 13 & $2 \mathrm{~L}$ & Cao luong do & 8979 & Laos & 33 & $33 \mathrm{~V}$ & Cua dua & 12274 & Vietnam \\
\hline 14 & $14 \mathrm{~V}$ & Bo bo & 8980 & Vietnam & 34 & $34 \mathrm{~V}$ & Luoi nguon lach & 12275 & Vietnam \\
\hline 15 & $15 \mathrm{~V}$ & Cao luong do & 8981 & Vietnam & 35 & $35 \mathrm{~V}$ & Cao luong & 12276 & Vietnam \\
\hline 16 & $16 \mathrm{~V}$ & Oi nong nang & 8983 & Vietnam & 36 & $36 \mathrm{~V}$ & Oi ta men & 12277 & Vietnam \\
\hline 17 & $17 \mathrm{~V}$ & Ma khau te & 8984 & Vietnam & 37 & $37 \mathrm{~V}$ & Co oi duoi men & 12278 & Vietnam \\
\hline 18 & $18 \mathrm{~V}$ & Coi chung rai hieng & 8986 & Vietnam & 38 & $38 \mathrm{~V}$ & Bong chua & 12280 & Vietnam \\
\hline 19 & $19 \mathrm{~V}$ & Oi luoi liem & 8987 & Vietnam & 39 & $39 \mathrm{~V}$ & Oc kien to & 12806 & Vietnam \\
\hline 20 & $20 \mathrm{~V}$ & Cao luong & 8988 & Vietnam & 40 & $40 \mathrm{~V}$ & Oi niem & 12807 & Vietnam \\
\hline
\end{tabular}


Table 1. Cont.

\begin{tabular}{|c|c|c|c|c|c|c|c|c|c|}
\hline No & $\begin{array}{l}\text { Variety } \\
\text { name }\end{array}$ & Local name & $\begin{array}{l}\text { Registered } \\
\text { number+ }\end{array}$ & Origin & No & $\begin{array}{l}\text { Variety } \\
\text { name }\end{array}$ & Local name & $\begin{array}{l}\text { Registered } \\
\text { number }+\end{array}$ & Origin \\
\hline 41 & $41 \mathrm{~V}$ & Dua liet & 12807 & Vietnam & 54 & 54 & Oi manh & 13188 & Vietnam \\
\hline 42 & $42 \mathrm{~V}$ & Cao luong den & 12809 & Vietnam & 55 & $1 \mathrm{~A}$ & - & ICSV574 & ICRRISAT \\
\hline 43 & $43 \mathrm{~V}$ & Cao luong do & 12812 & Vietnam & 56 & $2 \mathrm{~A}$ & - & ICSV700 & ICRRISAT \\
\hline 44 & $44 \mathrm{~V}$ & Cao luong do & 12813 & Vietnam & 57 & $3 \mathrm{~A}$ & - & ICSV93046 & ICRRISAT \\
\hline 45 & $1 \mathrm{I}$ & UP Cus.1 & 12814 & India & 58 & $4 \mathrm{~A}$ & - & NTJ2 & ICRRISAT \\
\hline 46 & $2 \mathrm{I}$ & PARCSV7 & 12819 & India & 59 & $5 \mathrm{~A}$ & - & ICSR93034 & ICRRISAT \\
\hline 47 & $47 \mathrm{~V}$ & Ma manh & 12820 & India & 60 & $6 \mathrm{~A}$ & - & ICSV25263 & ICRRISAT \\
\hline 48 & $48 \mathrm{~V}$ & Nong dua & 13181 & Vietnam & 61 & $7 \mathrm{~A}$ & - & ICSV25264 & ICRRISAT \\
\hline 49 & $49 \mathrm{~V}$ & Cuon dua pa & 13182 & Vietnam & 62 & $8 \mathrm{~A}$ & - & ICSV25265 & ICRRISAT \\
\hline 50 & $50 \mathrm{~V}$ & Mia xoa & 13183 & Vietnam & 63 & $9 \mathrm{~A}$ & - & ICSV25272 & ICRRISAT \\
\hline 51 & $51 \mathrm{~V}$ & Oi manh & 13184 & Vietnam & 64 & $10 \mathrm{~A}$ & - & ICSV25273 & ICRRISAT \\
\hline 52 & $52 \mathrm{~V}$ & Oi manh & 13185 & Vietnam & 65 & $11 \mathrm{~A}$ & - & ICSV25274 & ICRRISAT \\
\hline 53 & $53 \mathrm{~V}$ & Mya xa & 13186 & Vietnam & 66 & $12 \mathrm{~A}$ & - & ICSV25281 & ICRRISAT \\
\hline
\end{tabular}

-: no local name; + Registered number: Number of variety registered in Vietnam Gene Bank. 


\subsection{Experiment 1: Preliminary Evaluation of Growth and Sugar Content}

The 66 sorghum cultivars were grown in the fields by conventional methods during spring and summer-autumn cropping seasons 2009. Two weeks after sowing, the seedlings were thinned to seven plants per $\mathrm{m}^{-2}$. At flowering stage, the plant stems were harvested in random and delivered immediately to laboratory. Then, they were cut into pieces, finely grounded, and its juice was filtered by filter papers. The sugar content (Brix\%) was determined using the sugar meter (Atago, Japan) with three replicates. However, only cultivars with the Brix $>8 \%$ were recorded and selected for a continuous evaluation in the summer-autumn cropping season. In addition, time of growth (d), plant height (m) and stem yield (tons $\mathrm{ha}^{-1}$ ) were also determined.

\subsection{Experiment 2: Growth and Sugar Contents in Different Location}

Among cultivars having a sugar content with Brix $>8.0 \%$, those least affected by pests, diseases, and drought, were selected for growing in the spring and summer-autumn cropping seasons of 2010 in 3 different locations of northern Vietnam: Hoa Binh, Phu Tho, and Bac Giang provinces; 13 varieties were used. In Vietnam, all principle ethanol factories using cassava as material, except for the Phu Tho factory that was installed by a duo-system to use both cassava and sugarcane for ethanol production. Therefore, except for Phu Tho province, Bac Giang, and Hoa Binh are also selected because of the following reasons: (i) the distance to the ethanol factory in Phu Tho province is less than $100 \mathrm{~km}$; and (ii) many areas of fields are hilly, abandoned, or used for for crops other than rice which can be altered for sweet sorghum cultivation. In Vietnam, the area for rice production is strictly managed to ensure food safety of the country without allowing replacement by non-food crop. The selected sweet sorghum cultivars were assessed for their stem yields (tons ha ${ }^{-1}$ ), sugar contents (Brix\%), and ethanol yields (tons $\mathrm{ha}^{-1}$ ).

The varieties were selected as grown in each location were as follows: Hoa Binh province, 1A, 4A, 5A, 7A; Phu Tho province, 3A, 4A, 5A, 7A; Bac Giang province, 1A, 3A, 4A, 7A. Stem yields, sugar contents, and ethanol yields of these varieties were investigated.

\subsection{Experiment 3: Effects of Sowing Times to Growth and Sugar Content}

From the trial conducted in the summer-autumn cropping season, the most promising cultivars with the highest stem yields, sugar contents, and ethanol yields were selected (cultivar 4A). From our previous trials testing the sweet sorghums in every month of the year for their growth and sugar content, we found that in northern Vietnam the sowing time between March-April gave the highest sugar contents and maximum sugar and biomass productivity (data not shown). The cultivar 4A was grown in similar fields in the 3 provinces of Hoa Binh, Phu Tho, and Bac Giang with different sowing times: 15 and 25 of March, and 5, 15, and 25 of April. The stem yields, sugar contents, and ethanol yields of this cultivar were examined. 


\subsection{Experiment 4: Effects of Sowing Densities on Growth and Sugar Content}

In analogy to experiment 3 , methodologies, locations, and measured categories were similar in this experiment 4. Sowing densities were 5.7, 7.0, 8.3, 9.6, and 10.9 plants $\mathrm{m}^{-2}$ and time of sowing was on April 5.

\subsection{Experiment 5: Effect of Sowing Densities on Tolerance against Major Pests and Diseases}

The infestation was assessed against major pests and diseases of sweet sorghum, including cutworm (Agrotis spp.), anthranose (Colletotrichum graminicola), rust (Puccinia purpurea), maize aphid (Rhopalosiphum maidis), sorghum aphid (Melanaphis saccari), and stem borer (Busseola fusca). Measurement on the infestation (\%) of these pests and diseases was conducted by conventional methods. Sowing time and densities were similar to experiment 4.

\subsection{Measuring Categories}

\subsubsection{Stem Yield}

Stems of sweet sorghums were cut by $5 \mathrm{~cm}$ from the surface, leaves were then removed. The fresh stems were weighed in fields and expressed in tons $\mathrm{ha}^{-1}$.

\subsubsection{Ethanol Yield}

The ethanol yield $\left(1 \mathrm{ha}^{-1}\right)$ was calculated according to a method described in [34]: the ethanol yield = sugar content $($ Brix $\%) \times 6.5($ converting index $) \times 0.85$ (producing index $) \times$ stem yield (tons ha $\left.{ }^{-1}\right)$.

2.8.3. pH, Contents of N, P, K, Zn, Fe, Al, and OC and CEC in Soils

Measurement of soil $\mathrm{pH}$, content of $\mathrm{N}, \mathrm{P}, \mathrm{K}(\%)$, organic carbon (OC) (\%) and cation exchange capacity (CEC) $[\mathrm{cmol}(+) / \mathrm{kg}]$ and values of $\mathrm{Zn}, \mathrm{Fe}$, and $\mathrm{Al}\left(\mathrm{g} \mathrm{kg}^{-1}\right)$ were determined by conventional methods and conducted in VAAS (Vietnam Academy of Agricultural Science), Hanoi, Vietnam.

\subsection{Statistical Analysis}

Means and differences between the treatments were determined by using a balanced analysis of variance (ANOVA) with values of least significant difference (LSD) at 5\% level from IRRISTAT program version 5.0. For the analysis of effects of soil factors against stem yield, sugar content, and ethanol yield, data were expressed by mean \pm SE (Standard Errors). 


\section{Results}

\subsection{Experiment 1: Sugar Content and Growth of Sorghum}

\subsubsection{Spring Cropping Season 2009}

Among 66 cultivars, 21 were selected with a the Brix content $>8 \%$ (Table 2 ). Of them, variety $7 \mathrm{~A}$ yielded the highest sugar content (15\%), followed by the varieties $4 \mathrm{~A}, 5 \mathrm{~A}$, and $6 \mathrm{~A}(14 \%), 12 \mathrm{~A}(13 \%)$, and $2 \mathrm{~A}$ and $3 \mathrm{~A}(12 \%)$. Cultivars $19 \mathrm{~V}$ and $41 \mathrm{~V}$ provided the lowest Brix content $(8 \%)$ and the others one between $9 \%-11 \%$.

For the plant height and stem yield, cultivar $4 \mathrm{~A}$ was the best with a stem yield of 60.4 tons $\mathrm{ha}^{-1}$ and plant height of $3.7 \mathrm{~m}$ (Table 2). In general, cultivars of 1-12A provided the highest stem yield (45.5-60.4 tons ha ${ }^{-1}$ ), while the cultivar 19A produced 38.5 tons $\mathrm{ha}^{-1}$. Cultivars 19-54 $\mathrm{V}$ exerted lower stem yields (42.0-45.5 tons ha ${ }^{-1}$ ), whereas cultivars $1 \mathrm{~L}$ and $2 \mathrm{~L}$ produced 38.5 and 45.5 tons $\mathrm{ha}^{-1}$.

Table 2. Cultivars with sugar content (Brix $>8.0 \%$ ) and plant growth in spring cropping season 2009.

\begin{tabular}{|c|c|c|c|c|c|}
\hline No & $\begin{array}{c}\text { Variety } \\
\text { name }\end{array}$ & $\begin{array}{c}\text { Time of growth } \\
\text { (day) }\end{array}$ & $\begin{array}{c}\text { Sugar content } \\
\text { (Brix\%) }\end{array}$ & Plant height (m) & $\begin{array}{l}\text { Stem yield } \\
\left(\text { ton ha }^{-1}\right)\end{array}$ \\
\hline 1 & $1 \mathrm{~L}$ & 125 & 11.0 & 3.8 & 45.5 \\
\hline 2 & $2 \mathrm{~L}$ & 95 & 11.0 & 2.5 & 38.5 \\
\hline 3 & $19 \mathrm{~V}$ & 125 & 8.0 & 3.2 & 45.5 \\
\hline 4 & $27 \mathrm{~V}$ & 120 & 9.0 & 2.4 & 42.0 \\
\hline 5 & $34 \mathrm{~V}$ & 95 & 10.0 & 2.2 & 42.0 \\
\hline 6 & $35 \mathrm{~V}$ & 120 & 11.0 & 3.6 & 45.5 \\
\hline 7 & $41 \mathrm{~V}$ & 122 & 8.0 & 3.2 & 42.0 \\
\hline 8 & $46 \mathrm{~V}$ & 125 & 9.5 & 3.2 & 43.4 \\
\hline 9 & $54 \mathrm{~V}$ & 123 & 10.0 & 2.4 & 43.4 \\
\hline 10 & $1 \mathrm{~A}$ & 130 & 10.0 & 3.9 & 49.0 \\
\hline 11 & $2 \mathrm{~A}$ & 130 & 12.0 & 3.7 & 49.0 \\
\hline 12 & $3 \mathrm{~A}$ & 127 & 12.0 & 4.0 & 49.0 \\
\hline 13 & $4 \mathrm{~A}$ & 150 & 14.0 & 3.7 & 60.4 \\
\hline 14 & $5 \mathrm{~A}$ & 140 & 14.0 & 3.8 & 50.4 \\
\hline 15 & $6 \mathrm{~A}$ & 127 & 14.0 & 3.8 & 48.0 \\
\hline 16 & $7 \mathrm{~A}$ & 120 & 15.0 & 3.2 & 49.5 \\
\hline 17 & $8 \mathrm{~A}$ & 140 & 11.0 & 3.8 & 50.4 \\
\hline 18 & $9 \mathrm{~A}$ & 135 & 10.0 & 3.9 & 50.4 \\
\hline 19 & $10 \mathrm{~A}$ & 127 & 10.0 & 3.2 & 38.5 \\
\hline 20 & $11 \mathrm{~A}$ & 130 & 11.0 & 3.2 & 45.5 \\
\hline 21 & $12 \mathrm{~A}$ & 120 & 13.0 & 3.7 & 50.4 \\
\hline \multicolumn{2}{|c|}{ LSD 0.05} & 8.2 & 0.3 & 0.2 & 1.6 \\
\hline \multicolumn{2}{|c|}{$\mathrm{CV} \%$} & 12.5 & 1.7 & 4.3 & 2.1 \\
\hline
\end{tabular}


For the plant height, cultivar 1-12A $(3.2-4.0 \mathrm{~m})$ also showed higher plant height compared to $19 \mathrm{~V}-54 \mathrm{~V}$ with $2.2-3.6 \mathrm{~m}$, and $1 \mathrm{~L}, 2 \mathrm{~L}$ with 2.5 , and $3.8 \mathrm{~m}$. Growth time varied between 95-150 day (Table 2), however, there is no correlation between time of growth and sugar content. In general, varieties with high Brix values of $12 \%-15 \%$ ha have a growth time of $120-150$ day. Several cultivars have shorter growth periods of $95 \mathrm{~d}$, associated with a low sugar content of $10 \%-11 \%$ (Table 2 ).

\subsubsection{Summer-Autumn Cropping Season 2009}

There were only 11 among 66 cultivars showing a Brix value $>8 \%$; these were therefore selected (Table 3). The two cultivars $4 \mathrm{~A}$ and $7 \mathrm{~A}$ yielded the highest sugar content of $12 \%$ and $14 \%$.

The other varieties showed a Brix value of $8 \%-10 \%$. For the stem yield, the $4 \mathrm{~A}$ provided the maximum of 48.5 tons $\mathrm{ha}^{-1}$, followed by $5 \mathrm{~A}$ with 42.0 tons $\mathrm{ha}^{-1}$, while that of cultivar $7 \mathrm{~A}$ was lower with 38.5 tons $\mathrm{ha}^{-1}$. The stem yields of 28.0 tons ha ${ }^{-1}$ were similar for $27 \mathrm{~V}$ and $54 \mathrm{~V}$. Growth periods of this cropping season was shorter than that of the spring cropping season (110-125 day), while the plant height varied between 3.2-3.9 m. In general, these parameters did not proportionally correspond to the sugar content (Table 3 ).

Table 3. Sugar content (Brix $>8.0 \%$ ) and plant growth of selected cultivars in summer-autumn cropping season 2009.

\begin{tabular}{cccccc}
\hline No & $\begin{array}{c}\text { Variety } \\
\text { name }\end{array}$ & $\begin{array}{c}\text { Time of growth } \\
\text { (day) }\end{array}$ & $\begin{array}{c}\text { Sugar content } \\
\text { (Brix } \%)\end{array}$ & Plant height (m) & $\begin{array}{c}\text { Stem yield } \\
\text { (ton } \mathbf{h a}^{\mathbf{- 1}} \text { ) }\end{array}$ \\
\hline 1 & $1 \mathrm{~L}$ & 110 & 11.0 & 3.9 & 31.5 \\
2 & $27 \mathrm{~V}$ & 110 & 10.0 & 3.3 & 28.0 \\
3 & $35 \mathrm{~V}$ & 110 & 9.0 & 3.5 & 31.5 \\
4 & $46 \mathrm{~V}$ & 110 & 11.0 & 3.1 & 30.1 \\
5 & $54 \mathrm{~V}$ & 110 & 8.0 & 2.6 & 28.0 \\
6 & $3 \mathrm{~A}$ & 110 & 8.0 & 3.2 & 35.0 \\
7 & $4 \mathrm{~A}$ & 125 & 12.0 & 3.7 & 48.5 \\
8 & $5 \mathrm{~A}$ & 120 & 10.0 & 3.4 & 42.0 \\
9 & $7 \mathrm{~A}$ & 110 & 14.0 & 3.2 & 38.5 \\
10 & $8 \mathrm{~A}$ & 120 & 10.0 & 3.8 & 38.5 \\
11 & $9 \mathrm{~A}$ & 115 & 8.0 & 3.3 & 38.5 \\
& LSD 0.05 & 5.0 & 0.3 & 0.2 & 1.4 \\
& CV $\%$ & 12 & 4.5 & 5.1 & 2.3 \\
\hline
\end{tabular}

\subsection{Experiment 2: Growth and Sugar Contents in Different Locations}

\subsubsection{Spring Cropping Season 2010}

Results in Table 4 revealed that cultivars $4 \mathrm{~A}$ and $7 \mathrm{~A}$ were the most excellent to yield the highest sugar content (15.7\% and 15.9\%, respectively) and ethanol yield (5914.7 and $4329.3 \mathrm{~L} \mathrm{ha}^{-1}$, respectively). However, the stem yield, sugar content, and ethanol yield differed between locations. Of them, the trials conducted in Phu Tho province were the maximum, 1628.7-5914.7 tons $\mathrm{ha}^{-1}$ ), followed by Bac Giang province (1401.1-3911.7 tons $\mathrm{ha}^{-1}$ ), and Hoa Binh province obtained the lowest yield (1068.8-3264.7 $\mathrm{L} \mathrm{ha}^{-1}$ ). The stem yield and sugar content were similar, of them the trials 
in Phu Tho province achieved the highest (52.3-74.6 tons $\mathrm{ha}^{-1}$ and 9.3\%-15.9\% of Brix, respectively), and the least was that of Hoa Binh province (28.8-62.2 tons $\mathrm{ha}^{-1}$ and 8.3\%-12\% of Brix, respectively). Correspondingly, the ethanol yield in Phu Tho province was also the greatest $\left(1628.7-5914.7 \mathrm{~L} \mathrm{ha}^{-1}\right)$, whereas Hoa Binh province was the least efficacious (1068.8-3593.5 tons ha ${ }^{-1}$ ) (Table 4).

Table 4. Stem yield, sugar content, and ethanol yield of selected sweet sorghum cultivars in different locations in spring cropping season 2010.

\begin{tabular}{|c|c|c|c|c|c|c|c|c|c|c|}
\hline \multirow{2}{*}{ No } & \multirow{2}{*}{ Cultivars } & \multicolumn{3}{|c|}{ Stem yield (ton ha- } & \multicolumn{3}{|c|}{ Sugar content (Brix\%) } & \multicolumn{3}{|c|}{ Ethanol yield $\left(\mathrm{L} \mathrm{ha}^{-1}\right)$} \\
\hline & & $\mathbf{I}$ & II & III & $\mathbf{I}$ & II & III & I & II & III \\
\hline 1 & $1 \mathrm{~A}$ & 35.0 & 74.6 & 51.6 & 12.0 & 12.2 & 14.0 & 2320.5 & 3297.3 & 3186.8 \\
\hline 2 & $2 \mathrm{~A}$ & 52.8 & 74.6 & 62.8 & 8.0 & 9.3 & 8.0 & 2333.7 & 2720.2 & 1401.1 \\
\hline 3 & $3 \mathrm{~A}$ & 62.2 & 70.0 & 62.2 & 9.5 & 13.0 & 12.0 & 3264.7 & 3906.1 & 2161.3 \\
\hline 4 & $4 \mathrm{~A}$ & 54.2 & 69.3 & 64.2 & 12.0 & 15.7 & 12.0 & 3593.5 & 5914.7 & 3911.7 \\
\hline 5 & $5 \mathrm{~A}$ & 28.8 & 56.0 & 64.7 & 10.7 & 13.7 & 8.0 & 1702.5 & 1949.2 & 1637.6 \\
\hline 6 & $6 \mathrm{~A}$ & 56.0 & 71.9 & 61.3 & 9.3 & 11.6 & 10.0 & 2877.4 & 4061.9 & 2187.9 \\
\hline 7 & $7 \mathrm{~A}$ & 33.3 & 50.3 & 44.2 & 12.0 & 15.9 & 14.0 & 1506.2 & 4329.3 & 2923.8 \\
\hline 8 & $8 \mathrm{~A}$ & 33.3 & 57.4 & 54.8 & 9.7 & 11.7 & 8.0 & 1248.7 & 2219.9 & 1794.5 \\
\hline 9 & $9 \mathrm{~A}$ & 49.8 & 53.6 & 45.4 & 8.0 & 11.0 & 9.0 & 2201.1 & 1776.8 & 1750.3 \\
\hline 10 & $11 \mathrm{~A}$ & 32.7 & 65.3 & 60.7 & 8.0 & 11.5 & 10.0 & 1264.6 & 2994.4 & 2099.5 \\
\hline 11 & $12 \mathrm{~V}$ & 36.5 & 68.6 & 55.7 & 8.3 & 10.5 & 10.0 & 1264.6 & 3600.6 & 1701.7 \\
\hline 12 & $35 \mathrm{~V}$ & 34.2 & 53.6 & 46.7 & 9.2 & 10.5 & 9.6 & 1738.3 & 1628.7 & 2227.6 \\
\hline 13 & $46 \mathrm{~V}$ & 36.5 & 52.3 & 35.5 & 8.0 & 11.4 & 100 & 1068.8 & 3294.11 & 2297.2 \\
\hline \multicolumn{2}{|c|}{ LSD 0.05} & \multicolumn{3}{|c|}{0.7} & \multicolumn{3}{|c|}{0.7} & \multicolumn{3}{|c|}{2407.7} \\
\hline \multirow{2}{*}{\multicolumn{2}{|c|}{ CV\% }} & \multicolumn{3}{|c|}{0.8} & \multicolumn{3}{|c|}{3.9} & \multicolumn{3}{|c|}{55.7} \\
\hline & & \multicolumn{9}{|c|}{ I: Hoa Binh province; II: Phu Tho province; III: Bac Giang province. } \\
\hline
\end{tabular}

\subsubsection{Summer-Autumn Cropping Season 2010}

Based upon the results obtained from the spring cropping season 2010, selected cultivars including 1A, 4A, 5A, and 7A; 3A, 4A, and 5A, and 7A; 1A, 3A, 4A, and 7A were grown in Hoa Binh, Phu Tho, and Bac Giang provinces, respectively. Of them, the cultivars 4A and 7A were cultivated in every location (Table 5). In general, trials of Phu Tho showed the highest stem yield, sugar content, and ethanol yield, whilst those of Hoa Binh and Bac Giang varied among cultivars.

The ethanol yields of cultivars 4A and 7A in Phu Tho province were the greatest (5832.7 and 4195.6 tons $\mathrm{ha}^{-1}$, respectively), however no significant difference among means were found. 
Table 5. Stem yield, sugar content, and ethanol yield of selected sweet sorghum cultivars in different locations in summer-autumn cropping season 2010.

\begin{tabular}{|c|c|c|c|c|}
\hline Locations & Cultivars & $\begin{array}{c}\text { Stem yield } \\
\text { (ton ha }^{-1} \text { ) }\end{array}$ & Sugar content (Brix\%) & $\begin{array}{c}\text { Ethanol yield } \\
\left(\text { ton } \text { ha }^{-1}\right)\end{array}$ \\
\hline \multirow{4}{*}{ I } & $1 \mathrm{~A}$ & 55.3 & 11.0 & 3360.9 \\
\hline & $4 \mathrm{~A}$ & 65.3 & 12.0 & 4221.1 \\
\hline & $5 \mathrm{~A}$ & 52.6 & 9.5 & 2789.9 \\
\hline & $7 \mathrm{~A}$ & 45.3 & 14.3 & 3579.0 \\
\hline \multirow{4}{*}{ II } & $3 \mathrm{~A}$ & 67.1 & 13.0 & 4816.6 \\
\hline & $4 \mathrm{~A}$ & 69.1 & 15.3 & 5832.7 \\
\hline & $5 \mathrm{~A}$ & 62.4 & 11.3 & 3895.2 \\
\hline & $7 \mathrm{~A}$ & 50.0 & 15.2 & 4195.6 \\
\hline \multirow{4}{*}{ III } & $1 \mathrm{~A}$ & 40.1 & 11.3 & 2512.1 \\
\hline & $3 \mathrm{~A}$ & 50.1 & 11.0 & 3163.9 \\
\hline & $4 \mathrm{~A}$ & 65.3 & 12.3 & 4450.5 \\
\hline & $7 \mathrm{~A}$ & 43.2 & 14.2 & 3389.3 \\
\hline \multicolumn{2}{|c|}{ LSD 0.05} & 5.5 & 0.4 & 1870.5 \\
\hline \multicolumn{2}{|c|}{$\mathrm{CV} \%$} & 8.2 & 1.7 & 45.7 \\
\hline \multicolumn{5}{|c|}{ I: Hoa Binh province; II: Phu Tho province; III: Bac Giang province } \\
\hline
\end{tabular}

\subsubsection{Effects of Soils on Stem Yield, Sugar Content, and Ethanol Yield}

Stem yield, sugar content, and ethanol yield of cultivars 4A and 7A which were grown in both Spring and Summer-Autumn seasons and in every location were averaged and expressed by means \pm SE (Standard Errors) and determined the correlation with soil factors, including $\mathrm{pH}$, percentage of $\mathrm{N}, \mathrm{P}, \mathrm{K}$, and $\mathrm{OC}$ (organic carbon) (\%), CEC (cation exchange capacity) [cmol(+) $\left.\mathrm{kg}^{-1}\right]$, and content of $\mathrm{Zn}, \mathrm{Fe}$, and $\mathrm{Al}\left(\mathrm{g} \mathrm{kg}^{-1}\right)$ (Table 6).

Among three locations, Phu Tho province with type I soil produced significantly higher ethanol yields associated with higher stem yields and sugar contents than those of Hoa Binh and Bac Giang provinces with type II and III soils. Among soil factors of the three locations, the $\mathrm{pH}$ value, $\mathrm{K} \%$, and content of Fe of soil type I were significantly higher than those of types II and III (Table 6), whereas contents of Al and OC of soil type II was lower than that of types I and III. Quantity of Zn of types II and III was markedly higher than that of type I, while the value of N, P, OC, and CEC was negligibly different among the soils.

Higher productivity (stem yield and sugar content) and ethanol yield of sweet sorghum are associated with pH 5.5, contents of Fe and $\mathrm{Al}$ are 43.2 and $39.4 \mathrm{~g} \mathrm{~kg}^{-1}$, and $\mathrm{Zn}$ value of $0.6 \mathrm{~g} \mathrm{~kg}^{-1}$ (Table 6) to yield ethanol yield $>5000 \mathrm{~L} \mathrm{ha}^{-1}$. Content of zinc of soil type $\mathrm{I}\left(0.1 \mathrm{~g} \mathrm{~kg}^{-1}\right)$ was significantly higher than types II and III ( 0.6 and $0.5 \mathrm{~g} \mathrm{~kg}^{-1}$, respectively) and may explain the reduction of stem yield, sugar content, and ethanol yield of sweet sorghum. Other factors may contribute to productivity differences among sweet sorghum varieties. The lower amount of Al in soil type II $\left(39.4 \mathrm{~g} \mathrm{~kg}^{-1}\right)$ may also result in stronger growth and higher ethanol yield. However, the role of $\mathrm{Fe}$ in the soils was unclear and was not proportional to biomass and ethanol yield of the crop by this study. 
Table 6. Effects of soil factors to stem yield, sugar content, and ethanol yield.

\begin{tabular}{|c|c|c|c|c|c|c|c|c|c|c|c|c|}
\hline \multirow[b]{2}{*}{ Locations } & \multicolumn{9}{|c|}{ Soil factors } & \multirow[b]{2}{*}{$\begin{array}{c}\text { Stem yield } \\
\left(\text { ton } \mathrm{ha}^{-1}\right)\end{array}$} & \multirow[b]{2}{*}{$\begin{array}{l}\text { Sugar content } \\
\text { (Brix\%) }\end{array}$} & \multirow[b]{2}{*}{$\begin{array}{c}\text { Ethanol yield } \\
\left(\text { ton } \mathbf{h a}^{-1}\right)\end{array}$} \\
\hline & $\mathbf{p H}$ & $\mathbf{N}(\%)$ & $\mathbf{P}(\%)$ & $\mathbf{K}(\%)$ & OC $(\%)$ & $\begin{array}{c}\text { CEC } \\
{[\mathrm{cmol}(+) / \mathbf{k g}]}\end{array}$ & $\mathrm{Zn}\left(\mathrm{g} \mathrm{kg}^{-1}\right)$ & $\mathrm{Fe}\left(\mathrm{g} \mathrm{kg}^{-1}\right)$ & $\mathrm{Al}\left(\mathrm{g} \mathrm{kg}^{-1}\right)$ & & & \\
\hline I & $6.0 \pm 0.2$ & $0.2 \pm 0.01$ & $0.1 \pm 0.01$ & $1.0 \pm 0.3$ & $1.1 \pm 0.2$ & $7.9 \pm 1.1$ & $0.1 \pm 0.02$ & $56.0 \pm 7.5$ & $44.1 \pm 11.6$ & $49.5 \pm 5.9$ & $12.6 \pm 0.5$ & $3225.0 \pm 512.8$ \\
\hline II & $5.5 \pm 0.3$ & $0.2 \pm 0.01$ & $0.1 \pm 0.01$ & $0.3 \pm 0.1$ & $0.8 \pm 0.2$ & $8.5 \pm 1.2$ & $0.6 \pm 0.1$ & $43.2 \pm 10.8$ & $39.4 \pm 9.8$ & $59.7 \pm 4.8$ & $15.5 \pm 0.1$ & $5065.8 \pm 402.7$ \\
\hline III & $5.3 \pm 0.2$ & $0.1 \pm 0.01$ & $0.2 \pm 0.02$ & $0.4 \pm 0.1$ & $1.3 \pm 0.2$ & $7.5 \pm 0.5$ & $0.5 \pm 0.1$ & $37.3 \pm 8.5$ & $43.4 \pm 9.8$ & $54.2 \pm 5.2$ & $13.1 \pm 0.5$ & $3668.8 \pm 285.4$ \\
\hline \multicolumn{13}{|c|}{ I: Hoa Binh province; II: Phu Tho province; III: Bac Giang province. } \\
\hline
\end{tabular}

Data are means $\pm \mathrm{SE}$ (standard errors).

Table 7. Comparison of stem yield, sugar content, and ethanol yield between the two cropping seasons in 2010.

\begin{tabular}{|c|c|c|c|c|c|c|c|c|c|}
\hline \multirow{2}{*}{$\begin{array}{c}\text { Cropping } \\
\text { seasons } \\
\end{array}$} & \multicolumn{3}{|c|}{ Stem yield (ton ha ${ }^{-1}$ ) } & \multicolumn{3}{|c|}{ Sugar content (Brix\%) } & \multicolumn{3}{|c|}{ Ethanol yield (ton $\mathrm{ha}^{--1}$ ) } \\
\hline & I & II & III & I & II & III & I & II & III \\
\hline Spring & $41.9 \pm 3.7$ & $62.9 \pm 3.1$ & $54.6 \pm 3.1$ & $9.6 \pm 0.5$ & $12.1 \pm 0.7$ & $10.3 \pm 0.6$ & $2029.6 \pm 273.3$ & $3207.2 \pm 400.9$ & $2252.0 \pm 235.4$ \\
\hline Summer-autumn & $54.6 \pm 4.1$ & $62.2 \pm 4.3$ & $49.7 \pm 5.6$ & $11.7 \pm 1.0$ & $13.7 \pm 1.0$ & $12.2 \pm 0.7$ & $3487.7 \pm 295.7$ & $4685.0 \pm 428.0$ & $3379.0 \pm 402.7$ \\
\hline
\end{tabular}

Data are mean $\pm \mathrm{SE}$ (standard errors). 


\subsubsection{Effects of Cropping Seasons on Productivity and Ethanol Yield}

The values of stem yield, sugar content, and ethanol yield of cultivars cultivated in spring and the summer-autumn cropping season of 2010 differed substantially (Table 7). In general, the summer-autumn provided a significantly higher productivity regarding stem yield, sugar content, and ethanol yield as compared to the spring seasons. The ethanol yield was increased $>1000 \mathrm{t} \mathrm{ha}^{-1}$ in every cultivating location.

\subsection{Experiment 3: Effects of Sowing Times on Growth and Sugar Content}

In this trial, only cultivar 4A was cultivated in the three provinces during the spring cropping season 2011 with different sowing times (15 and 25 March; 5, 15, and 25 April) (Table 6). For the stems, the sowing time between 25 March-15 April provided the highest yield (50.0-64.0 tons ha ${ }^{-1}$ ), with the Phu Tho province reaching the maximum of60.0-62.0 tons ha ${ }^{-1}$. By 15 March-25 April, the stem yield was markedly reduced, but the sugar content did not strongly vary among sowing times $(12.0 \%-13.7 \%$ of Brix), and locations (Table 8).

Regarding ethanol, the period of 25 March-15 April produced the highest yield with 3487.4-4510.5 tons $\mathrm{ha}^{-1}$, whereas by 5 April it was the best with 4510.5 tons $^{-1} \mathrm{ha}^{-1}$. The sowing time at 25 April provided significant lower ethanol yields of 2552.6-3356.4 tons $\mathrm{ha}^{-1}$ compared to that of 15 March with 2784.6-3315.1 tons ha $^{-1}$.

Table 8. Effect of sowing times to stem yield, sugar content, and ethanol yield of the 4A cultivar grown in different locations in spring cropping season 2011.

\begin{tabular}{|c|c|c|c|c|c|c|c|c|c|}
\hline \multirow{2}{*}{ Sowing time } & \multicolumn{3}{|c|}{ Stem yield (ton ha $\mathrm{ha}^{-1}$ ) } & \multicolumn{3}{|c|}{ Sugar content (Brix\%) } & \multicolumn{3}{|c|}{ Ethanol yield $\left(\mathrm{L} \mathrm{ha}^{-1}\right)$} \\
\hline & $\mathbf{I}$ & II & III & $\mathbf{I}$ & II & III & $\mathbf{I}$ & II & III \\
\hline 15 March & 42.0 & 50.5 & 45.0 & 12.0 & 12.0 & 12.7 & 2784.6 & 3315.1 & 3157.5 \\
\hline $25 \mathrm{March}$ & 52.0 & 62.0 & 50.2 & 12.5 & 12.0 & 13.5 & 3591.3 & 4110.6 & 3744.3 \\
\hline 5 April & 52.5 & 64.0 & 50.8 & 12.0 & 12.0 & 13.7 & 3487.4 & 4510.5 & 3845.2 \\
\hline 15 April & 52.6 & 60.0 & 50.0 & 12.0 & 12.0 & 13.7 & 3487.3 & 3978.1 & 3784.6 \\
\hline 25 April & 38.5 & 42.5 & 45.3 & 12.0 & 12.0 & 13.5 & 2552.6 & 2817.7 & 3356.4 \\
\hline LSD 0.05 & \multicolumn{3}{|c|}{0.4} & \multicolumn{3}{|c|}{0.4} & \multicolumn{3}{|c|}{28.1} \\
\hline $\mathrm{CV} \%$ & \multicolumn{3}{|c|}{0.8} & \multicolumn{3}{|c|}{3.2} & \multicolumn{3}{|c|}{0.8} \\
\hline \multicolumn{10}{|c|}{ I: Hoa Binh province; II: Phu Tho province; III: Bac Giang province } \\
\hline
\end{tabular}

\subsection{Experiment 4: Effects of Sowing Densities on Growth and Sugar Content}

In this experiment, only the cultivar 4A was used. There were 5 different sowing densities of 5.7, 7.0, 8.3, 9.6, 10.9 plants $\mathrm{m}^{-2}$, examined in similar locations in Hoa Binh, Phu Tho, and Bac Giang provinces (Table 9).

For locations similar to findings of Table 6, trials of Phu Tho province showed the highest stem yields, sugar contents, and ethanol yields compared to those of other provinces. The densities at 8.3-10.9 plants $\mathrm{m}^{-2}$ resulted in higher stem yields, sugar contents, and ethanol yields compared to the densities of 5.7-7.0 plants $\mathrm{m}^{-2}$. The sugar content of the density 8.3 plants $\mathrm{m}^{-2}$ was either similar (Hoa Binh province) or lower (Phu Tho and Bac Giang provinces) than that of other growing densities, , indicates that the density of 8.3 plants $\mathrm{m}^{-2}$ was the ideal condition to cultivate the sweet sorghum cultivar $4 \mathrm{~A}$. 
Table 9. Effect of sowing densities to stem yield, sugar content, and ethanol yield of the 4A cultivar grown in different locations in spring cropping season 2011.

\begin{tabular}{|c|c|c|c|c|c|c|c|c|c|}
\hline \multirow{2}{*}{ Density (plant $\mathrm{m}^{-2}$ ) } & \multicolumn{3}{|c|}{ Stem yield (ton $\mathrm{ha}^{-1}$ ) } & \multicolumn{3}{|c|}{ Sugar content (Brix\%) } & \multicolumn{3}{|c|}{ Ethanol yield $\left(\mathrm{L} \mathrm{ha}^{-1}\right)$} \\
\hline & $\mathbf{I}$ & II & III & $\mathbf{I}$ & II & III & I & II & III \\
\hline 5.7 & 41.0 & 44.0 & 48.2 & 13.5 & 15.0 & 11.0 & 3054.4 & 3642.4 & 2929.4 \\
\hline 7.0 & 54.3 & 65.5 & 55.6 & 13.5 & 15.0 & 10.3 & 4050.1 & 5428.3 & 3164.1 \\
\hline 8.3 & 78.8 & 80.8 & 74.8 & 13.5 & 13.0 & 10.7 & 5874.5 & 5799.9 & 4422.0 \\
\hline 9.6 & 64.3 & 72.3 & 66.8 & 13.5 & 15.0 & 10.4 & 4794.0 & 5776.4 & 3838.3 \\
\hline 10.9 & 65.7 & 74.0 & 68.6 & 13.5 & 14.0 & 11.0 & 4896.7 & 5723.9 & 4169.2 \\
\hline LSD 0.05 & \multicolumn{3}{|c|}{0.7} & \multicolumn{3}{|c|}{0.1} & \multicolumn{3}{|c|}{53.9} \\
\hline $\mathrm{CV} \%$ & \multicolumn{3}{|c|}{0.6} & \multicolumn{3}{|c|}{2.1} & \multicolumn{3}{|c|}{0.7} \\
\hline \multicolumn{10}{|c|}{ ho province; III: Bac Giang province } \\
\hline
\end{tabular}

\subsection{Experiment 5: Effect of Sowing Densities on Tolerance against Major Pests and Diseases}

Growing densities similar to experiment 4 as conducted in Hoa Binh, Phu Tho, and Bac Giang provinces examined the effects against major pests and diseases of cultivar $4 \mathrm{~A}$ including cutworm (Agrotis spp.), anthracnose (C. graminicola), rust (P. purpurea), maize aphid ( $R$. maidis), sorghum aphid (M. saccari), and stem borer (B. fusca). However, the cutworm was not detected (Table 10).

Table 10. Effect of sowing densities to tolerance of major pests and diseases of the cultivar 4A grown in different locations in spring cropping season 2011.

\begin{tabular}{|c|c|c|c|c|c|c|c|}
\hline Locations & Density (plant $\mathrm{m}^{-2}$ ) & a (\%) & b (\%) & c $(\%)$ & d (\%) & e (\%) & $f(\%)$ \\
\hline \multirow{5}{*}{ I } & 5.7 & 0.0 & 2.6 & 10.5 & 8.0 & 8.1 & 41.2 \\
\hline & 7.0 & 0.0 & 2.5 & 10.6 & 7.6 & 8.3 & 40.5 \\
\hline & 8.3 & 0.0 & 2.8 & 11.2 & 8.1 & 8.5 & 42.4 \\
\hline & 9.6 & 0.0 & 3.1 & 11.5 & 8.5 & 8.2 & 52.7 \\
\hline & 10.9 & 0.0 & 3.3 & 11.6 & 8.5 & 9.2 & 58.3 \\
\hline \multirow{5}{*}{ II } & 5.7 & 0.0 & 2.2 & 9.3 & 7.1 & 7.9 & 40.0 \\
\hline & 7.0 & 0.0 & 3.0 & 9.6 & 7.3 & 7.6 & 41.4 \\
\hline & 8.3 & 0.0 & 2.6 & 10.4 & 8.2 & 9.0 & 43.5 \\
\hline & 9.6 & 0.0 & 3.1 & 12.4 & 8.4 & 9.0 & 54.1 \\
\hline & 10.9 & 0.0 & 3.4 & 12.8 & 8.3 & 9.2 & 57.7 \\
\hline \multirow{5}{*}{ III } & 5.7 & 0.0 & 2.4 & 12.3 & 7.2 & 8.1 & 42.4 \\
\hline & 7.0 & 0.0 & 2.8 & 13.0 & 7.5 & 8.2 & 42.2 \\
\hline & 8.3 & 0.0 & 2.8 & 13.0 & 9.1 & 8.6 & 42.2 \\
\hline & 9.6 & 0.0 & 2.8 & 10.7 & 8.2 & 7.8 & 54.0 \\
\hline & 10.9 & 0.0 & 2.4 & 11.4 & 8.3 & 8.2 & 58.1 \\
\hline \multicolumn{2}{|l|}{ LSD 0.05} & & 0.1 & 0.4 & 0.3 & 0.3 & 3.1 \\
\hline \multicolumn{2}{|l|}{$\mathrm{CV} \%$} & & 0.2 & 0.2 & 0.4 & 0.2 & 2.6 \\
\hline \multicolumn{2}{|c|}{ a: Cutworm (Agrotis spp.) } & \multicolumn{6}{|c|}{ b: Anthracnose (Colletotrichum graminicola) } \\
\hline \multicolumn{2}{|c|}{ c: Rust (Puccinia purpurea) } & \multicolumn{6}{|c|}{ d: Maize aphid (Rhopalosiphum maidis) } \\
\hline \multicolumn{2}{|c|}{ e: Sorghum aphid (Melanaphis saccari) } & \multicolumn{6}{|c|}{ f: Stem borer (Busseola fusca) } \\
\hline \multicolumn{2}{|c|}{ I: Hoa Binh province } & \multicolumn{3}{|c|}{ II: Phu Tho province } & \multicolumn{3}{|c|}{ III: Bac Giang province } \\
\hline
\end{tabular}


For the anthracnose, the percentage of infestation was proportional to the sowing densities, however the magnitude of infestation was low $(2.2 \%-3.4 \%)$, with little differences among the three provinces. The affected percentages of rust, maize aphid, and sorghum aphid were greater than that of the anthracnose $(9.3 \%-13.0 \%, 7.2 \%-8.5 \%, 7.6 \%-9.2 \%$, respectively). The most harmful pest was the stem borer that affected $40.0 \%-58.3 \%$ of the cultivar $4 \mathrm{~A}$ (Table 10 ). The infestation level was proportional to the sowing densities and most pronounced with 9.6-10.9 plants $\mathrm{m}^{-2}$.

\section{Discussion}

This study provides for the first time a detailed cultivating protocol for sweet sorghum. Although this crop can be grown in any location of the northern Vietnam, Phu Tho province was the most appropriate place to provide optimum stem yield, sugar content, and ethanol yield (Tables 4 and 5). Vietnam is endowed with some large-scale ethanol factories with production capacities of up to $100,000 \mathrm{~L} \mathrm{day}^{-1}$ ethanol, while the factory with the highest production is located in Phu Tho province, uniquely equipped by a dual system to be used for both cassava and sugarcane.

The spring cropping season showed lower productivity of biomass and ethanol yield than those of the summer-autumn cropping season. This suggests that sweet sorghum can be cultivated twice a year by using cultivars with short growth time of 95-110 day (Tables 2 and 3). With a sugar content of 15.7\%, and an ethanol yield of $5914.7 \mathrm{~L} \mathrm{ha}^{-1}$, cultivar 4A was the most promising cultivar for ethanol production. This figure was much higher than the result of Davila-Gomez [35] obtained from five different varieties of sweet sorghum, providing a stem yield of 74.6 tons $\mathrm{ha}^{-1}$; which is similar to the average yield of 36 sorghum cultivars in Iran [36] and is dramatically higher the research result from Cifuentes et al. [37] and Aruna et al. [38], which was only 42.15 tons $\mathrm{ha}^{-1}$. According to a study of Imam [39], sorghum fermentation increases the ethanol production to more than $6000 \mathrm{~L} \mathrm{ha}^{-1}$, associated with a $100 \%$ efficiency.

This study clarifies for the first time that the season of sowing was important to increase the growth, biomass, and ethanol yield of sweet sorghum (Tables 6 and 7). The sowing time between March 25 to April 15 gave the highest stem yield, but between March 15 to April 25, the stem yield was significantly reduced from 50.0-64.0 tons $\mathrm{ha}^{-1}$ to 38.5-45.3 tons ha $\mathrm{ha}^{-1}$ (Table 8).

Sweet sorghum is a $\mathrm{C}_{4}$ crop with fast growth and strong competition for space, light, nutrient, and allelopathy. Therefore, the sowing density can strongly influence sugar content and biomass yield. By this study, the density of 8.3 plants $\mathrm{m}^{-2}$ was ideal for sweet sorghum cultivation providing the highest sugar content and biomass (Table 9). Optimum sowing time and densities are indispensable for the growing protocol for sweet sorghum to help providing higher economic efficacy in ethanol production.

Unlike the common sorghum, sweet sorghum attacks many pests and diseases as it has a much higher sugar content. Among them, cutworm (Agrotis spp.), anthranose (C. graminicola), rust (P. purpurea), maize aphid (R. maidis), sorghum aphid (M. saccari), and stem borer (B. fusca) are the major destructive causes of crop growth and yield [39]. Except for the stem borer, the cultivar 4A was little affected by infestation of the other pests and diseases, with anthracnose as the lowest $(2.2 \%-3.4 \%)$; rust, maize aphid, and sorghum aphid was found in a slightly higher magnitude of 7.2\%-13.0\% (Table 10). Similar to maize, the destruction of the stem borer against the cultivar $4 \mathrm{~A}$ was found in $40.0 \%-58.5 \%$, indicating that this pest is the major constrain for sweet sorghum production. The infestation level was not proportional to the sowing densities, suggesting that the sowing density could not control the destruction 
of this pest. Despite much effort to search for sweet sorghum cultivars resistant against stem borer has been conducted, successful control has not yet been approached [39]. The breeding of sweet sorghum with the Bt-resistant gene may be a solution to control this pest in enhancing productivity of sweet sorghum for ethanol production.

The content of $\mathrm{Zn}$ in soil type I was significantly lower than in types II and III (Table 6), likely explained by its higher $\mathrm{pH}$ than that of types II and III (Table 6). Haldar and Mandal [40] reported that high $\mathrm{pH}$ increases the solution of phosphorous, which in turn decreased the concentrations of zinc, copper, and manganese in soybean. Therefore, the $\mathrm{pH}$ of 6.0 may cause lower zinc contents in soil type I and result in the reduction of sweet sorghum productivity of stems and sugar contents and ethanol yields than those of soils type II and III. The lower Al contents in soils may also contribute to the higher growth and ethanol yield of sweet sorghum (Table 6). There was no significant difference among amounts of N, P, OC, and CEC in the studied soils. The amount of Fe was not proportional to the increased biomass, sugar content, and ethanol yield of sweet sorghum.

It may be questioned why organic fertilizers such as manure were not applied in this research. Recently, the combination of different doses of organic and chemical fertilizers on growth and ethanol yield of two sweet sorghum cultivars has been examined [41]. It was concluded that organic fertilizers may be better for soil properties, but chemical fertilizers cause higher biomass and ethanol yield. To increase nutrients and maintain the sustainability of soils, the use of a crop rotation such as legume crops after cultivation of sweet sorghum is suggested. In addition, in developing countries including Vietnam, with the unstable and sporadic management of cattle raising, it is rather difficult to accumulate enough manures for a large area for sweet sorghum cultivation, such as 10,000 ha for a manufacture producing ethanol. Therefore, the use of a sustainable cropping system is required, of which legume crops and vegetable are preferred. The combination of chemical fertilizers and microbial fertilizers are common to enhance soil nutrients and crop productivity.

Through its course of economic development, Vietnam has moved from being an economy based on subsistence farming to becoming a major agricultural exporter [42]. The staple food is rice, which accounts for 13.1 billion USD or $28 \%$ of total the agricultural production. The other food crops which can be used for ethanol production have a much lower economic efficacy than rice, indicating that there is no significant impact to the food security of the country. For instance, possible food crops for ethanol production in Vietnam consist of corn, cassava, sugar cane, and sweet potatoes but they have a much lower percentage of total agricultural production than rice $(3.0 \%, 3.0 \%, 2.0 \%$, and $1.0 \%$, respectively) [43]. Similar to sweet sorghum, corn, cassava, and sugar cane, are cultivated in uplands; therefore, ethanol production by these crops and sweet sorghum do not provide detrimental impact to the stability of food production and economy of the country.

One common way of evaluating the energy balance of a fuel is the net energy return on investments (EROI) [42]. EROI is the ratio of energy delivered by a process to total (fossil and other) energy used directly and indirectly in that process. A EROI result greater than 1.0 indicates that the biofuel is a net energy provider, and for most ethanol and diesel EROI is higher than 1.0. For instance, the EROI index of ethanol of sweet sorghum is $0.7-1.0$, whereas that of cassava, sugarcane, sugar beet, wheat and corn is 1.3-1.9, 3.1-9.3, 1.2, 1.6-5.8, and 0.8-1.7, respectively [44]. The economic efficacy of growing sweet sorghum in Vietnam comparing with other crops was compared, in North of Vietnam, production of sweet sorghum provides interest of 73.2 million VND/ha (US\$3476, US \$ $1=21,000$ VND equivalent), 
whereas that of cassava, sugarcane, and maize was 19.0 (US\$904.8), <52.5 (US\$2500), <30.8 million VND (US\$1,467), respectively [45]. It is clear that for the production of ethanol in Vietnam, sweet sorghum is more beneficial for farmers than cassava, sugarcane and maize.

The costs of biofuels are of major considerations. Biofuels must be competitive with each other and with mineral fuels such as petrol and diesel. This competition ensures a market for the biofuel, as people will have an incentive to convert to a renewable source of energy. The following main approaches can be distinguished in the implementation of biofuels, supporting policies and regulation: (1) taxation-based policies, (2) agriculture-based policies/subsidies, and (3) fuel mandates [45]. The price of the raw materials is highly volatile, which can strongly influence the production cost of ethanol, and feed stock represents $60 \%-75 \%$ of the total ethanol production cost [6]. Ethanol from sugar cane in Brazil costs US\$ 0.23-0.29 $\mathrm{L}^{-1}$ [46], while the EU and United States sugar and corn-derived ethanol cost USD\$ 0.29 [47] and US\$ $0.53 \mathrm{~L}^{-1}$ [48], respectively.

The cultivation of sweet sorghum can save $1 / 2$ and $2 / 3$ water demand as compared to that of maize and sugarcane, respectively, lessens use of fertilizers, and improves tolerance of the crop to salinity and drought [26]. Therefore, sweet sorghum is more appropriate and economical than maize and sugarcane in cultivate land with irrigation shortage and dry climate. Consumptive water use by ethanol plants largely comes from evaporation during cooling and wastewater discharge. Ethanol plants are designed to recycle water within the plants. Water utilization is estimated as 10 gallons ( 1 gallon corresponds to $3.78541178 \mathrm{~L}$ ) per min for each 1 million gallons of yearly ethanol production. Thus, a typical 50 million gallons per year ethanol plant may need 500 gallons per min of water [48]. There is no publicly available record on water use by ethanol plants but modern ethanol plantations have sophisticated water treatment techniques to enable recycling of water to boilers. These treatment techniques enable the plants to use water of lower quality such as sewage treatment plant effluents [48]. The system use for sweet sorghum is similar to that for sugar cane; therefore, similar amounts of water may be needed during distillation in ethanol manufacture plants.

Mainly, three types of raw materials, that is, sugar juice, starchy crops, and lignocellulosic materials, are being used for ethanol production. However, lignocellulosic materials are being studied and developed in laboratory because of low efficacies of economic and ethanol yield [49]. Current industrial fermentation for fuel ethanol production uses two types of feedstocks including free fermentable sugars and starch, juices containing free sugars are more economical than starch feedstocks as the former can directly be employed in fermentation without any prior treatment. However, better yield also depends somewhat on the selection of microorganisms and fermentation modes and techniques as well as the influence of several factors, for instance, temperature, $\mathrm{pH}$, fermentation time, agitation rate, initial sugar concentration, and inoculum size [49] However, in an industrial plant of ethanol production, these factors are well controlled. Therefore, selection and development of different potential genetic varieties of juice producing crops will also enhance the commercial ethanol production.

In Vietnam, as well as many countries in Southeast Asia, sorghum has been long known as a food crop. However, as rice is the staple food, the sorghum starch is rarely used in Southeast Asia and East Asia. To provide sufficient sweet sorghum to a factory with a capacity of 100,000 L ethanol production day $^{-1}$, it requires an area of 10,000 ha to cultivate sweet sorghum. Therefore, the cultivation of sweet sorghum for ethanol production can be enforced in developing countries in the tropics because of low labor cost and vast arable land. The cultivative protocol established by this study is useful for farmers not 
only in Vietnam but also in most developing countries toward the growing and development of sweet sorghum for ethanol production.

\section{Acknowledgments}

The authors express sincere thanks to Ministry of Trade, Vietnam for funding to this research. Thanks also due to Rolf Teschke for his assistance to this manuscript.

\section{Author Contributions}

Nguyen Thi Phuong is responsible for the cultivation of sweet sorghum, whist Tran Dang Khanh provides advice on ethanol production. Tran Dang Xuan is the coordinator and prepares the manuscript with Do Tan Khang.

\section{Conflicts of Interest}

The authors declare no conflict of interest.

\section{References}

1. Fischer, A.; Oehm, C.; Selle, M.; Werner, P. Biotic and abiotic transformations of methyl tertiary butyl ether (MTBE). Environ. Sci. Pollut. Res. Int. 2005, 12, 381-386.

2. Belpoggi, F.; Soffritti, M.; Maltoni, C. Methyl tertiary-butyl ether (MTBE) - A gasoline additiveCauses testicular and lymphohaematopoetic cancers in rats. Toxicol. Ind. Health. 1995, 11, 119-149.

3. Cassada, D.A.; Zhang, Y.; Snow, D.D.; Spalding, R.F. Trace analysis of ethanol, MTBE, and related oxygenate compounds in water using solid-phase microextraction and gas chromatography/mass spectrometry. Anal. Chem. 2000, 72, 4654-4658.

4. Drapcho, C.M.; Nhuan, N.P.; Walker, T.H. Biofuels Engineering Process Technologies; The McGraw-Hill Companies: New York, NY, USA, 2008.

5. Almodares, A.; Hadi, M.R. Production of bioethanol from sweet sorghum: A review. Afr. J. Agric. Res. 2009, 4, 772-780.

6. Balat, M.; Balat, H. Recent trends in global production and utilization of bio-ethanol fuel. Appl. Energy 2009, 86, 2273-2282.

7. Yoosin, S.; Sorapipanata, C. A study of ethanol production cost for gasoline substitution in Thailand and its competitiveness. Thammasat Int. J. Sci. Technol. 2007, 12, 69-80.

8. Pulidindi, I.N.; Kimchi, B.B.; Gedanken, A. Can cellulose be a sustainable feedstock for bioethanol production? Renew. Energy 2014, 71, 77-80.

9. Wang, M.; Chen, Y.; Xia, L.; Li, J.; Liu, J. Energy efficiency and environmental performance of bioethanol production from sweet sorghum stem based on life cycle analysis. Bioresour. Tech. 2014, 163, 74-81.

10. Yu, M.; Li, J.; Chang, S.; Du, R.; Li, S.; Zhang, L.; Fan, G.; Yan, Z.; Cui, T.; Cong, G.; et al. Optimization of ethanol production from $\mathrm{NaOH}-$ pretreated solid state fermented sweet sorghum bagasse. Energy 2014, 7, 4054-4067. 
11. Mahmood, S.; Gulfraz, M.; Tahir, M.S.; Rehman, M.S.; Aqil, T.; Mahmood, T. Statistical screening and selection of sweet sorghum varieties for bioethanol production. Pakistan J. Bot. 2014, 46, $1115-1120$.

12. Hattori, T.; Morita, S. Energy crops for sustainable bioethanol production; which, where and how. Plant Prod. Sci. 2010, 13, 221-234.

13. Fernandes, G.; Braga, T.G.; Fischer, J.; Farrella, R.A.C.; Resende, M.M.; Cardoso, V.L. Evaluation of potential ethanol production and nutrients for four varieties of sweet sorghum during maturation. Renew. Energy 2014, 71, 518-524.

14. Marx, S.; Ndaba, B.; Chiyanzu, I.; Schabort, C. Fuel ethanol production from sweet sorghum bagasse using microwave irradiation. Biomass Bioenergy 2014, 65, 145-150.

15. Almodares, A.; Taheri, R.; Chung, M.; Fathi, M. The effect of nitrogen and potassium fertilizer on growth parameters and carbohydrate content of sweet sorghum cultivars. J. Environ. Biol. 2008, 29, 849-852.

16. Li, J.; Li, S.; Han, B.; Yu, M.; Li, G.; Jiang, Y. A novel cost-effective technology to convert sucrose and homocelluloses in sweet sorghum stalks into ethanol. Biotechnol. Biofuels 2013, 6, 174-184.

17. Curt, M.D.; Fernandez, J.; Martinez, M. Productivity and water use efficiency of sweet sorghum (Sorghum bicolor (L.) Moench) cv. "Keller" in relation to water regime. Biomass Bioenergy 1995, 8, 401-409.

18. Hanh, V.T.; Phuong, L.T.B.; Hung, L.T. Sustainable ethanol production in Vietnam: Current status and proposed solutions. In Proceedings of the 9th Biomass-Asia Workshop, Tokyo, Japan, 3-4 December 2012.

19. Andrew, A.S.; Jiang, J. Biofuels Annual: China's 2014 fuel ethanol production is forecast to increase six percentage. Available online: http:/gain.fas.usda.gov/Recent\%20GAIN\%20Publications/ Biofuels\%20Annual_Beijing_China\%20-\%20Peoples\%20Republic\%20of_11-4-2014.pdf (accessed on 5 March 2015).

20. FAO. Food Outlook-Global Market Analysis. Available online: http://www.fao.org/docrep/ 016/a1993e/a1993e00.pdf (accessed on 4 March 2015).

21. Phuong, D.T.; Hoa, T.T.K.; Tuan, V.A. Production of bio-oil from rice straw in Vietnam. Petrol Times 2010, 12, 44-49.

22. Nguyen, H.D.; Huynh, Q.N. Rong bien Vietnam (Marine algae of North Vietnam); Science and Technology Publisher: Hanoi, Vietnam, 1993; p. 364. (In Vietnamese)

23. JICA. JICA supports Vietnam developing the sustainable integration of local agriculture and biomass industries. Available online: http://www.jica.go.jp/vietnam/english/office/topics/pdf/ press0906.pdf (accessed on 9 March 2015).

24. Diep, Q.N.; Fujimoto, S.; Minowa, T.; Sakanishi, K.; Nakagoshi, N. Estimation of the potential of rice straw for ethanol production and the optimum facility size for different regions in Vietnam. Appl. Energy 2012, 93, 205-211.

25. Chen, S.-F.; Danao, M.-G.C.; Singh, V.; Brown, P.J. Determining sucrose and glucose levels in dual-purpose sorghum stalks by Fourier transform near infrared (FT-NIR) spectroscopy. J. Sci. Food Agric. 2014, 94, 2569-2576.

26. Vinutha, K.S.; Rayaprolu, L.; Yadagiri, K. Sweet sorghum research and development in India: Status and prospects. Sugar Tech. 2014, 16, 133-143. 
27. Blummel, M.; Rao, S.S.; Palanisvwami, S.; Shah, L.; Reddy, B.S.V. Evaluation of sweet sorghum (Sorghum bicolor (L.) Moench) used for bio-ethanol production in the context of optimizing whole plant utilization. Anim. Nutr. Feed Technol. 2009, 11, 239-245.

28. Ratnavathi, C.; Kumar, S.; Kumar, B.; Krishna, D.; Patil, J. Effect of time of planting on cane yield and quality characters in sweet sorghum. J. Sustain. Bioenergy Syst. 2012, 2, 1-9.

29. Duncan, R.R. The influence of soil pH on sorghum grain yields. Comm. Soil Sci. Plant Anal. 1991, 22, 1605-1616.

30. Mahama, G.Y.; Prasad, P.V.V.; Mengel, D.B.; Tesso, T.T. Influence of nitrogen fertilizer on growth and yield of grain sorghum hybrids and inbred lines. Agron. J. 2014, 106, 1623-1630.

31. Hussein, M.M.; Alva, A.K. Growth, yield, and water use efficiency of forage sorghum as affected by NPK fertilizer and deficit irrigation. Am. J. Plant Sci. 2014, 5, 2134-2140.

32. Soleymani, A.; Shahrajabian, M.H. The effects of Fe, Mn, and $\mathrm{Zn}$ foliar application on yield, ash and protein percentage of forage sorghum in climatic condition of Esfahan. Intel. J. Biol. 2012, 4, 92-96.

33. Samac, D.A.; Tesfaye, M. Plant improvement for tolerance to aluminum in acid soils - A review. Plant Cell Tissue Organ Cult. 2003, 75, 189-207.

34. Lipnsky, E.S. Fuels from Sugar Crops; Columbus Laboratories, Battelle Memorial Institute; Department of Energy: Washington, DC, USA, 1978.

35. Davila-Gomez, F.J.; Chuck-Hernandez, C.; Perez-Carrillo, E.; Rooney, W.L.; Serna-Saldivar, S.O. Evaluation of bioethanol production from five different varieties of sweet and forage sorghums (Sorghum bicolor (L.) Moench). Crop Prot. 2011, 33, 611-616.

36. Bhairappanavar, S.T.; Sharanappa. Bio-ethanol production potential of sweet sorghum (Sorghum bicolor) cultivars under different spacing and harvest stages. Indian J. Agron. 2011, 56, $52-56$.

37. Cifuentes, R.; Bressani, R.; Rolz, C. The potential of sweet sorghum as a source of ethanol and protein. Energy Sustain. Dev. 2014, 21, 13-19.

38. Aruna, C.; Priya, A.R.; Neeraja, C.N.; Patil, J.V.; Visarada, K.B.R.S. Diversity analysis using ISSR markers for resistance to shoot pests in sorghum. Crop Prot. 2012, 35, 110-117.

39. Shama, H.C. Host-plant resistance to insects in sorghum and it role in integrated pest management. Crop Prot. 1993, 12, 11-34.

40. Haldar, M.; Mandal, L.N. Effects of phosphorous and zinc on the growth and phosphorus, zinc, copper, iron and management nutrition of rice. Plant Soil. 1981, 59, 414-425.

41. Xuan, T.D.; Yang, A. Influence of fertilization on growth, biomass, and sugar content of sweet sorghum. In Proceedings of the 2nd Asia Conference on Biomass Science (ACBS2015), Tsukuba, Japan, 13 January 2015.

42. Krumdieck, S.; Page, S. Retro-analysis of liquid bio-ethanol and bio-diesel in New Zealand. Energy Policy 2014, 62, 363-371.

43. Arita, S.S.; Dyck, J. Vietnam's agri-food sector and the Trans-Pacific Partnership. Available online: http://www.ers.usda.gov/media/1692699/eib130.pdf (accessed on 10 August 2015).

44. Nakagoshi, N.; Phuong, N.T.; Xuan, T.D. Selection of potential sweet sorghum for bioethanol production in Vietnam. In Proceedings of 9th Biomass-Asia Workshop: "Role of Biomass as Renewable Energy", Tokyo, Japan, 3-4 December 2012. 
45. Smith, A.M. Prospects for increasing starch and sucrose yields for bioethanol production. Plant J. 2008, 54, 546-558.

46. Kojima, M.; Johnson, T. Potential for Biofuels for Transport in Developing Countries; World Bank: Washington, DC, USA, 2005.

47. Mitchell, D. A Note on Rising Food Prices; World Bank: Washington, DC, USA, 2008.

48. Keeney, S.; Muller, M. Water Use by Ethanol Plants: Potential Challenges; Institute for Agriculture and Trade Policy: Minneapolis, MN, USA, 2006.

49. Zabed, H.; Farug, G.; Sahu, J.N.; Azirun, M.S.; Hashim, R.; Boyce, A.N. Bioethanol production from fermentable sugar juice. E. Sci. World J. 2014, doi:10.1155/2014/957102.

(C) 2015 by the authors; licensee MDPI, Basel, Switzerland. This article is an open access article distributed under the terms and conditions of the Creative Commons Attribution license (http://creativecommons.org/licenses/by/4.0/). 